\title{
A Statistical study Regarding Knowledge and Risk Factors of Hepatitis B and C in Muzaffarabad Azad Jammu \& Kashmir
}

\author{
Atif Abbasi ${ }^{1}$, Azhar Saleem ${ }^{1}$, Samarah Aqeel Butt ${ }^{1}$, Nazneen Habib ${ }^{2}$,Wafa \\ Hussain $^{2}$, Sheeba Arooj ${ }^{2}$ \\ ${ }^{I}$ (Department of Statistics, University of Azad Jammu \& Kashmir Muzaffarabad) \\ 2(Department of Sociology and Rural Development, University of Azad Jammu \& Kashmir Muzaffarabad)
}

\begin{abstract}
Background: Hepatitis B and C is considered to be a significant threat to the mankind around the globe. Hepatitis is one of the major viral disease affecting significant proportion of population not only in developing countries but also in developed countries. This threat is most alarming in developing countries where poverty, illiteracy may contribute to the high risk for causes of Hepatitis B and C Pakistan is highly endemic for Hepatitis $B$ and $C$. Objective: The objective of the present study were to investigate the risk factor of hepatitis among the people of Muzaffarabad Azad Jammu \& Kashmir and also to check the prevalence of hepatitis $B$ and $C$ in the presence of different risk factors. And to investigate the relationship between education, area and gender with hepatitis. Methods: a cross-sectional descriptive study was conducted over a sample of 400 respondents based on multistage sampling technique. The chi-square test was used to assess the statistical significance to different risk factors with blood transfusion. The multiple logistic regression, Mann-Whitney $U$ test and Kruskal-Wallis $H$ test were also used to get the most significant risk factors of hepatitis $B$ and $C$. Results: the study shows that the most dominant risk factors of the hepatitis $B$ and $c$ that were age group 15-20 $(O R=2.621), 21-26(O R=1.344) 27-31(O R=1.005)$ with 95\% CI. Marital status that is married $(O R=0.438)$ Un-married $(O R=0.850)$, education at different level that is Primary $(O R=0.728)$, Secondary $(O R=0.973)$, graduate $(O R=0.688)$, knowledge about hepatitis $B$ and $C$, yes $(O R=1.412)$, No $(O R=1.547)$, history of ear piercing $(O R=1.401)$, Re-use of syringes $(O R=1.250,2.498)$, sexual relation with affected person $(O R=3.943$, 1.877). Mann-Whitney $U$ test with gender and area of the respondents with values $(15759.500, p$-value $=.005)$ and (18907.00, p-value=.266).It was found that there is difference between male and female opinion regarding knowledge about hepatitis $B$ and $C$ there was same knowledge about risk factor of hepatitis $B$ and $C$ among the people of rural and urban areas. The study shows that the educated people have more awareness and knowledge regarding hepatitis $B$ and $C$.
\end{abstract}

Key Words: Chi-Square; Hepatitis $B$ and C; Logistic Regression; Mann-Whitney $U$ test; Odd Ratio,Muzaffarabad

\section{Introduction}

Human beings are at risk due to infinite number of disease. From these infinite numbers of diseases some are identified and some are still unidentified. Hepatitis B virus and hepatitis C virus infection is one of them.

A viral hepatitis caused by the hepatitis B virus is known as HBV also called serum hepatitis. The virus is transmitted by transfusion of contaminated/infected blood or blood products, by sexual contact with an infected person, by using contaminated needles and instruments. It can cause acute and chronic hepatitis. Severe infection may cause prolonged illness, destruction of liver cells, cirrhosis, increased risk of liver cancer, or death. Vaccination against HBV is recommended for infants, teenagers, and adults at risk for exposure. Treatment may involve transplantation.

A viral disease caused by the hepatitis $\mathrm{C}$ virus is known as $\mathrm{HCV}$, commonly occurring after transfusion or parenteral drug abuse; it frequently progresses to a chronic form that is usually asymptomatic but that may involve cirrhosis.

Chronic and acute viral hepatitis is global health problem and common public health problems in Pakistan ${ }^{[1]}$. The word hepatitis means the inflammation of the liver. Pakistan carries one of the world's highest burdens of chronic hepatitis and mortality due to liver failure and hepatocellular carcinomas. Despite efforts at different levels, incidence is increasing day by day. Hepatitis B virus (HBV) and hepatitis C virus (HCV) infections account for a substantial proportion of liver diseases worldwide. These viruses are responsible for liver damages ranging from minor disorders to liver cirrhosis and hepatocellular carcinoma (HCC). Approximately 2 billion people in the world have been infected by HBV, and more than 350 million are chronic carriers of the virus. Hepatitis $\mathrm{C}$ virus $(\mathrm{HCV})$ infection affects approximately 180 million people worldwide. HBV infection accounts annually for 1 million deaths worldwide from cirrhosis, liver failure, and hepatic cellular carcinoma. The prevalence rate is about $10 \%$ for HBV and 4-7\% for HCV in Pakistan ${ }^{[2]}$. 
Combined HBV and HCV infection is possible because of common modes of viral transmission ${ }^{[3]}$. The two most common Ways through which chronic and acute hepatitis spread in Pakistan are by injection and blood transfusion. Other causes, incidence and risk factors such as unchecked blood transfusion in thalasema or peoples on haemodialysis, regular contact with blood at work, IDUs, receiving blood and its products, Received a tattoo, ear piercing, surgery etc with contaminated instruments, sharing of personal items such as tooth brush, razors with infected person or involved in sexual abuse are at increased risk of developing these infections ${ }^{[5]}$. During birth, a mother with hepatitis B or C can pass hepatitis B or C on her infant. Study to decide the seroprevalence of hepatitis B virus (HBV) and hepatitis $\mathrm{C}$ virus (HCV) infections and the possible risk factors among blood donors in Nyala, South Dar Fur State of western Sudan, which has never been consider before. A total of 400 male blood Donors were tested for the exposure of HBsAg (Hepatitis B Surface Antigen) and anti$\mathrm{HCV}$ antibodies, $(6.25 \%)$ were establish Immediate for $\mathrm{HBsAg}$ and $(0.65 \%)$ were immediate for anti-HCV antibodies. The study accomplished that the sero-prevalence of HBV and HCV was in middle and low rates respectively and insecure sexual activities was the major risk factor for infection in the population studied ${ }^{[7]}$.

Therefore the present study was conducted to have an idea about the knowledge regarding different risk factors of hepatitis B and C in the people of Azad Jammu and Kashmir Muzaffarabad.In our knowledge this is a first study about that serious issue mentioned above.

.Although there are many ways of passing, the virus actually is not very easily transmitted. There is no need to worry that casual contact, such as shaking hands, will expose one to hepatitis B or C. There is no reason not to share a workplace or even a restroom with an infected person. The some major symptoms that can occur in hepatitis is usually abdominal pain, dark urine, fatigue, jaundice, itching, vomiting, colored stool and nausea.

Both $\mathrm{HBV}$ and $\mathrm{HCV}$ are the blood born viruses. Both $\mathrm{HCV}$ and $\mathrm{HBV}$ can be detected by rapid assay test, ELISA (Enzyme Link Immune Sorbent Assay) and PCR (Polymerase Chain Reaction). Prevention is the only way to cope with the epidemic of viral hepatitis and screening provides an opportunity to detect the virus in its asymptomatic and helps early diagnosis and management. Screening programs are now widely used to detect the virus in peoples with prior infection of hepatitis $\mathrm{B}$ and $\mathrm{C}$ and helps to prevents in complications ${ }^{[5]}$.

In the past, there was no treatment available for hepatitis B and C. But developments have been made in recent years on drugs that suppress the virus and its symptoms. The prevention/treatment of hepatitis B is (a) Active Immunization and (b) Passive Immunization (Hep. B Immunoglobulin) where as in hepatitis C, the alpha interferon therapy is given for treatment but it is effective only in $30 \%$ of the peoples.

The best way to prevent any form of viral hepatitis is to avoid contact with blood and other body fluids of infected individuals. The use of condoms during sex also is advisable. Babies born of a mother with HBV should receive the vaccine within 24 hours. An effective and safe vaccine is available that reliably prevents hepatitis B. Vaccination is suggested for most infants and for children aged 10 and younger whose parents are from a place where hepatitis B is common. Teenagers not vaccinated as children and all adults at risk of exposure also should be vaccinated against hepatitis. Three doses are recommended ${ }^{[6]}$.

\section{Methodology}

The objective of the study were to investigate the risk factors of hepatitis among the people of Muzaffarabad Azad Jammu \& Kashmir and also check the prevalence of hepatitis B and C in the presence of different risk factors. A cross sectional descriptive study was conducted in district Muzaffarabad. A sample of 400 respondents was taken who visited the hospitals in Abbas Institute of Medical Sciences Muzaffarabad and Sheikh Khalifa Bin Zaid al nahyan Hospital Muzaffarabad based on multistage sampling technique. A structured close ended questionnaire was used to collect the information from the respondents. Questionnaire were distributed randomly to well trained staff nurses who collected the information from the respondents visited in hospitals. Data was analyzed using SPSS version 13.

\section{Results and Discussion}

As discussed earlier that sample size of 400 respondents were selected for the current study.

Table 1. Feedback of the respondents about the knowledge about hepatitis B and C.

\begin{tabular}{llcc}
\hline & & Frequency & Percentage \\
\hline Age & $15-20$ & 61 & 15.3 \\
\cline { 2 - 4 } & $21-26$ & 140 & 35.0 \\
\cline { 2 - 4 } & $27-31$ & 123 & 30.8 \\
\cline { 2 - 4 } & & 731 & 19.0 \\
\cline { 2 - 4 } Gender & Total & $\mathbf{4 0 0}$ & $\mathbf{1 0 0 . 0}$ \\
\hline
\end{tabular}




\begin{tabular}{|c|c|c|c|}
\hline & female & 143 & 35.8 \\
\hline & Total & 400 & 100.0 \\
\hline \multirow[t]{3}{*}{ Area } & urban & 202 & 50.5 \\
\hline & rural & 198 & 49.6 \\
\hline & Total & 400 & 100.0 \\
\hline \multirow[t]{4}{*}{ Marital Status } & Married & 214 & 53.5 \\
\hline & Unmarried & 162 & 40.5 \\
\hline & Divorced & 24 & 6.1 \\
\hline & Total & 400 & 100.0 \\
\hline \multirow[t]{5}{*}{ Education } & Primary & 105 & 26.3 \\
\hline & Secondary & 161 & 40.3 \\
\hline & Graduate & 100 & 25.0 \\
\hline & post graduate & 34 & 8.5 \\
\hline & Total & 400 & 100.0 \\
\hline \multirow[t]{4}{*}{ Knowledge about Hepatitis B and C } & Yes & 258 & 64.5 \\
\hline & No & 82 & 20.5 \\
\hline & don't know & 60 & 15.0 \\
\hline & Total & 400 & 100.0 \\
\hline \multirow[t]{3}{*}{ How to screen hepatitis B and C } & blood test & 349 & 87.3 \\
\hline & sputum test & 51 & 12.8 \\
\hline & Total & 400 & 100.0 \\
\hline \multirow[t]{3}{*}{ History of liver disease? } & yes & 148 & 37.0 \\
\hline & no & 252 & 63.0 \\
\hline & Total & 400 & 100.0 \\
\hline \multirow[t]{3}{*}{ History of ear piercing } & yes & 148 & 37.0 \\
\hline & no & 252 & 63.0 \\
\hline & Total & 400 & 100.0 \\
\hline \multirow[t]{3}{*}{ History of tattoo } & yes & 89 & 22.3 \\
\hline & no & 311 & 77.8 \\
\hline & Total & 400 & 100.0 \\
\hline \multirow[t]{3}{*}{ History of surgery } & yes & 165 & 41.3 \\
\hline & no & 235 & 58.8 \\
\hline & Total & 400 & 100.0 \\
\hline \multirow[t]{3}{*}{ History of dental treatment } & yes & 211 & 52.8 \\
\hline & no & 189 & 47.3 \\
\hline & Total & 400 & 100.0 \\
\hline \multirow[t]{3}{*}{ Do you have blood transfusion ever? } & yes & 127 & 31.8 \\
\hline & no & 273 & 68.3 \\
\hline & Total & 400 & 100.0 \\
\hline \multirow{4}{*}{$\begin{array}{l}\text { Can hepatitis } \mathrm{B} \text { and } \mathrm{C} \text { spread through re- } \\
\text { using of syringes? }\end{array}$} & Yes & 208 & 52.0 \\
\hline & No & 87 & 21.8 \\
\hline & don't know & 105 & 26.3 \\
\hline & Total & 400 & 100.0 \\
\hline \multirow{4}{*}{$\begin{array}{l}\text { Can hepatitis } \mathrm{B} \text { and } \mathrm{C} \text { spread through } \\
\text { affected mother to child? }\end{array}$} & Yes & 183 & 45.8 \\
\hline & No & 91 & 22.8 \\
\hline & don't know & 126 & 31.5 \\
\hline & Total & 400 & 100.0 \\
\hline \multirow{4}{*}{$\begin{array}{l}\text { Can hepatitis B and C spread through prick } \\
\text { of ear and nose? }\end{array}$} & Yes & 192 & 48.0 \\
\hline & No & 91 & 22.8 \\
\hline & don't know & 117 & 29.3 \\
\hline & Total & 400 & 100.0 \\
\hline \multirow{4}{*}{$\begin{array}{l}\text { Can hepatitis B and } \mathrm{C} \text { spread through sexual } \\
\text { relation with affected person? }\end{array}$} & Yes & 181 & 45.3 \\
\hline & No & 95 & 23.8 \\
\hline & don't know & 124 & 31.0 \\
\hline & Total & 400 & 100.0 \\
\hline
\end{tabular}




\begin{tabular}{|c|c|c|c|}
\hline \multirow{3}{*}{$\begin{array}{l}\text { Have you ever suffered from Hepatitis B } \\
\text { and C? }\end{array}$} & No & 207 & 51.8 \\
\hline & yes & 193 & 48.3 \\
\hline & Total & 400 & 100.0 \\
\hline \multirow[t]{4}{*}{ Is it possible to save from hepatitis $B$ and $C$ ? } & Yes & 221 & 55.3 \\
\hline & No & 63 & 15.8 \\
\hline & don't know & 116 & 29.0 \\
\hline & Total & 400 & 100.0 \\
\hline \multirow{4}{*}{$\begin{array}{l}\text { Is there any treatment available for hepatitis } \\
\mathrm{B} \text { and } \mathrm{C} \text { ? }\end{array}$} & Yes & 142 & 35.5 \\
\hline & No & 80 & 20.1 \\
\hline & don't know & 178 & 44.5 \\
\hline & Total & 400 & 100.1 \\
\hline
\end{tabular}

The above table 1 shows that out of 400 respondents 61 were in the age group 15-20 years, while others 140 were in the age group 21-26 years, 123 were in the age group 27-31 years, and 76 were in the age group >31 years. $15.3 \%$ were in $15-20$ age group, $35.0 \%$ were in $21-26$ age group, $30.8 \%$ were in $27-31$ age group and $19.0 \%>31$ age group. Majority of respondents were in the age group 21-26 years. In this study, 64.3\% respondents were male and $35.8 \%$ were female. $50.5 \%$ of the respondents were from rural area and rest of the respondents were from urban A study by Ahmad et al. ${ }^{[7]}$ revealed the frequency of HBV and HCV amongst urban and rural population was $45 \%$ and 55\%, respectively. Out of 400 respondents, $214(53.5 \%)$ respondents were married, majority of the respondents $(40.3 \%)$ were having secondary education, $26.3 \%$ were primary educated, $25.0 \%$ were graduate and rest of the respondents were post-graduate $(8.5 \%)$. Majority of respondents 258 (64.5\%) had knowledge about Hepatitis B and C and 87.3\% knew that hepatitis B and C is detected by blood test. Out of 400 respondents, $63.0 \%$ had no family history about hepatitis and majority of $(43.3 \%)$ respondents get shave at their home and $28.5 \%$ get shave from barbers. History of piercing $(63.0 \%)$ and tattoo (77.8\%) was not found in majority of the respondents while history of surgery was found in $41.3 \%$ of the respondents and 58.8\% have no history of surgery. On the other hand, $52.8 \%$ get dental treatment and $47.3 \%$ did not have dental treatment ever. Majority of respondents $68.3 \%$ were in favor that hepatitis can be transmit through blood transfusion while $52.2 \%$ were in favor that hepatitis can be transmit through re-using of syringes. 45.5\% respondents knew that hepatitis can be transmitting through effected mother to child while $31.5 \%$ have no idea about that. Similarly, $45.3 \%$ were in favor that hepatitis can be transmit through having sex with effected person while $31.0 \%$ have no idea about this risk factor. 55.3\% of the respondents were agreed that it is possible to save from hepatitis by adopting precautionary measures and treatment. $35.5 \%$ knew that there is treatment available for hepatitis (see table 1).

Table 2. Prevalence of Hepatitis B and C in the presence of different risk factors

\begin{tabular}{|c|c|c|c|c|c|c|}
\hline \multirow{2}{*}{\multicolumn{2}{|c|}{ Variables }} & \multirow{5}{*}{$\begin{array}{l}\text { d.f } \\
1 \\
1 \\
1\end{array}$} & \multirow{5}{*}{$\begin{array}{l}\text { Odds ratio } \\
2.621 \\
1.344 \\
1.005 \\
1\end{array}$} & \multirow{5}{*}{$\begin{array}{l}\mathrm{p} \text {-value } \\
0.055 \\
0.028 \\
0.011\end{array}$} & \multicolumn{2}{|c|}{$95 \%$ C-I } \\
\hline & & & & & lower & Upper \\
\hline Age & $15-20$ & & & & 0.978 & 7.024 \\
\hline & $21-26$ & & & & 0.647 & 2.793 \\
\hline & $\begin{array}{l}27-31 \\
>31(\mathrm{r})\end{array}$ & & & & 0.491 & 2.054 \\
\hline Sex & $\begin{array}{l}\text { Male } \\
\text { Female(r) }\end{array}$ & 1 & 0.856 & 0.019 & 0.312 & 2.346 \\
\hline Area & $\begin{array}{l}\text { Urban } \\
\text { Rural (r) }\end{array}$ & 1 & .751 & 0.041 & 0.441 & 1.278 \\
\hline Marital status & $\begin{array}{l}\text { Married } \\
\text { Unmarried } \\
\text { Divorced(r) }\end{array}$ & $\begin{array}{l}1 \\
1\end{array}$ & $\begin{array}{l}0.438 \\
0.850 \\
1\end{array}$ & $\begin{array}{l}0.001 \\
0.049\end{array}$ & $\begin{array}{l}0.139 \\
0.260\end{array}$ & $\begin{array}{l}1.379 \\
2.776\end{array}$ \\
\hline Education & $\begin{array}{l}\text { Primary } \\
\text { Secondary } \\
\text { Graduate } \\
\text { Post graduate(r) }\end{array}$ & $\begin{array}{l}1 \\
1 \\
1\end{array}$ & $\begin{array}{l}0.728 \\
0.973 \\
0.688 \\
1\end{array}$ & $\begin{array}{l}0.001 \\
0.000 \\
0.021\end{array}$ & $\begin{array}{l}0.253 \\
0.371 \\
0.263\end{array}$ & $\begin{array}{l}2.093 \\
2.553 \\
1.805\end{array}$ \\
\hline $\begin{array}{l}\text { Knowledge about hepatitis B } \\
\text { and C }\end{array}$ & $\begin{array}{l}\text { Yes } \\
\text { No } \\
\text { Don't know(r) }\end{array}$ & $\begin{array}{l}1 \\
1\end{array}$ & $\begin{array}{l}1.412 \\
1.547 \\
1\end{array}$ & $\begin{array}{l}0.000 \\
0.007\end{array}$ & $\begin{array}{l}0.639 \\
0.664\end{array}$ & $\begin{array}{l}3.122 \\
3.603\end{array}$ \\
\hline History of ear piercing & $\begin{array}{l}\text { Yes } \\
\text { No(r) }\end{array}$ & 1 & $\begin{array}{l}1.401 \\
1\end{array}$ & 0.011 & 0.747 & 2.626 \\
\hline
\end{tabular}




\begin{tabular}{|c|c|c|c|c|c|c|}
\hline Re-use of syringes & $\begin{array}{l}\text { Yes } \\
\text { No } \\
\text { Don't know(r) }\end{array}$ & $\begin{array}{l}1 \\
1\end{array}$ & $\begin{array}{l}1.250 \\
2.498\end{array}$ & $\begin{array}{l}0.012 \\
0.030\end{array}$ & $\begin{array}{l}0.650 \\
1.170\end{array}$ & $\begin{array}{l}2.401 \\
5.333\end{array}$ \\
\hline Affected mother to child & $\begin{array}{l}\text { Yes } \\
\text { No } \\
\text { Don't know(r) }\end{array}$ & $\begin{array}{l}1 \\
1\end{array}$ & $\begin{array}{l}1.126 \\
0.611 \\
1\end{array}$ & $\begin{array}{l}0.012 \\
0.030\end{array}$ & $\begin{array}{l}0.650 \\
1.170\end{array}$ & $\begin{array}{l}2.401 \\
5.333\end{array}$ \\
\hline Prick of ear and nose & $\begin{array}{l}\text { Yes } \\
\text { No } \\
\text { Don't know(r) }\end{array}$ & $\begin{array}{l}1 \\
1\end{array}$ & $\begin{array}{l}1.718 \\
0.928 \\
1\end{array}$ & $\begin{array}{l}0.016 \\
0.041\end{array}$ & $\begin{array}{l}0.562 \\
0.297\end{array}$ & $\begin{array}{l}2.255 \\
1.258\end{array}$ \\
\hline $\begin{array}{l}\text { Sexual relation with affected } \\
\text { person }\end{array}$ & $\begin{array}{l}\text { Yes } \\
\text { No } \\
\text { Don't know(r) }\end{array}$ & $\begin{array}{l}1 \\
1\end{array}$ & $\begin{array}{l}3.943 \\
1.877 \\
1\end{array}$ & $\begin{array}{l}0.015 \\
0.023\end{array}$ & $\begin{array}{l}0.884 \\
0.451\end{array}$ & $\begin{array}{l}3.339 \\
1.911\end{array}$ \\
\hline Affected blood & $\begin{array}{l}\text { Yes } \\
\text { No } \\
\text { Don't know(r) }\end{array}$ & $\begin{array}{l}1 \\
1\end{array}$ & $\begin{array}{l}1.384 \\
1.449 \\
1\end{array}$ & $\begin{array}{l}0.032 \\
0.040\end{array}$ & $\begin{array}{l}1.990 \\
0.917\end{array}$ & $\begin{array}{l}7.812 \\
3.840\end{array}$ \\
\hline
\end{tabular}

Table 2 shows the results of multiple logistic regression model with odd ratios and their 95\% confidence interval. The logistic regression model was used to check the significant risk factors of hepatitis B and C. In which we considered have you ever suffer in hepatitis Band C as binary response variable (yes or no) and the remaining variable such as age, sex, area, marital status, education, knowledge about hepatitis, history of ear piercing, re-use of syringes, affected mother to child, prick of ear and nose, sexual relation with affected person and affected blood were considered as independent variables.

It was observed that the peoples in the age group 15-20 years were 2.621 times more likely to have hepatitis B and C than the peoples whose age group was >31 years, similarly the people whose age group 21-26 years were 1.344 times more likely to have hepatitis $\mathrm{B}$ and $\mathrm{C}$ than the people whose age group was $>31$ years. Similarly the peoples whose age group 27-31 years were 1.005 times more likely to have hepatitis B and C than the people whose age group was $>31$ years and the $95 \%$ confidence interval for the odds ratio of the age group 15-20 years, 21-26 years and 27-31 years was also calculated and the limits for the age group 15-20 years were 0.978 to 7.024 and its p-value was 0.055 and limits for age group 21-26 years were 0.647 to 2.793 and its pvalue was 0.028 similarly for age group 27-31 years were 0.491 to 2.054.and its p-value was 0.011 it is observed that male were 0.856 times fewer chances to have hepatitis B and C than the female and the $95 \%$ confidence interval for the odds ratios were 0.312 to 2.346 . its p-value was $0.019 \mathrm{p}$-value is less than level of significance 0.05 , it shows significant results. The prevalence of hepatitis B surface antigen and anti-HCV antibody was high in patients below 50 years of age ${ }^{[10]}$. results of the study conducted by Abel the prevalence of HBV was highest, $16 / 26(61 \%)$ in the age group of 28-37 years but none $(0 \%)$ in age groups above 68 years. More urban dwellers, 34 (28.3\%) were HBsAg positive than rural dwellers, 9 (7.5\%). Married patients had prevalence of $23(19.2 \%)$, single were $15(12.5 \%)$ and widows, $3(1.7 \%)$.

It is observed that married peoples had 0.438 times less chances to have a hepatitis B and C as compared to divorced people, similarly unmarried people had 0.850 times less chances to have hepatitis B and C as compared to divorced peoples and 95\% confidence interval for married people was 0.139 to 1.379 and its pvalue was 0.011 and for unmarried people was 0.260 to 2.776 and its p-value was 0.049 the p-value is less than level of significance it shows significant results.

It was also observed that people who live in urban area have 0.751 times less chance to have hepatitis B and $\mathrm{C}$ as compared to the people who live in rural area.95\% confidence interval for odds ratios of urban area was 0.441 to 1.278 .and its p-value was 0.041 . Hepatitis infection in urban population may be due to the nature of living in which urban areas are densely populated as compared to rural areas and this might expose urban dwellers for different risk factors. The sociodemographic characteristics have not been significantly associated with acquisition of infection except history of dental extraction at health facility in HCV infection ${ }^{[10]}$.

It was also observed that people having primary education were 0.728 times less chances to have hepatitis B and C as compared to post graduate peoples, similarly the peoples who have secondary education were 0.973 times less chances to have hepatitis B and C as compared to post graduate and the respondents who have graduate education were 0.688 times less chances to have hepatitis B and C.95\% confidence interval for primary educated people were 0.253 to 2.093 and its p-value was 0.001 ,for secondary educated peoples were 0.371 to 2.553 and its p-value was 0.000 and for graduated people were 0.263 to 1.805 .and its p-value was 0.021 .

It was also observed that people who said yes that they aware about hepatitis have 1.412 times more knowledge about hepatitis as compared to the people who don't know about knowledge of hepatitis, similarly 
the people have 1.547 times more likely to have knowledge about hepatitis as compared to the people who don't know about the hepatitis.95\% confidence interval for those have knowledge about hepatitis were 0.639 to 3.122 and its p-value was 0.000 and for those have no knowledge about hepatitis were 0.664 to 3.603.and its p-value was 0.007 . The respondents having history of ear piercing were 1.401 times more likely to have hepatitis as compared to those having no history of ear piercing and 95\% confidence interval for those have history of ear piercing was 0.747 to 2.626 and its p-value was 0.011 and p-value is less than level of significance it shows significant results.

It was observed that hepatitis B and C spread 1.250 and 2.498 times more likely through re-use of syringes as compared to those who don't know whether it is spread through re-use of syringes, and $95 \%$ confidence interval was 0.650 to 2.401 and 1.170 to 5.33 respectively.

The risk of Hepatitis B and C spread 1.126 times more likely through affected mother to child as compared to those who don't know whether it is spread through affected mother to child, and $95 \%$ confidence interval was 0.562 to 2.255 and its p-value was 0.016 and for those who say it is not spread through affected mother to child were 0.297 to 1.258 .and its p-value was 0.041 . Hepatitis B and C spread 1.718 times more likely through prick of ear and nose as compared to those who don't know about whether it is spread through prick of ear and nose and $95 \%$ confidence interval was 0.884 to 3.339 and its p-value was 0.015 and for those who say it is not spread through prick of ear and nose was 0.451 to 1.911 and its p-value was 0.023 .

It was also observed that hepatitis Hepatitis B and C spread 3.943 and 1.877 times more through sexual relation with affected person as compared to those who don't know whether it is spread through sexual relation with affected person and $95 \%$ confidence limits were 1.990 to 7.812 and 0.917 to 3.840 respectively.

The risk of hepatitis spread 1.384 and1.449 times more likely through affected blood as compared to those who don't know whether it is spread through affected blood and $95 \%$ confidence interval was 0.714 to 2.680 and 0.711 to 2.954 respectively.

Table 3. Results of Chi-square test for association of blood transfusion with different variables.

\begin{tabular}{|l|c|c|}
\hline Variables & Chi-square value & p-value \\
\hline $\begin{array}{l}\text { Blood Transfusion* Is hepatitis B and C spread through re-use of } \\
\text { syringes }\end{array}$ & 21.330 & 0.000 \\
\hline Blood Transfusion*any family member have liver disease & 9.999 & 0.007 \\
\hline Blood Transfusion* History of ear piercing & 1.210 & .546 \\
\hline Blood Transfusion* history of tattoo & 10.392 & 0.006 \\
\hline Blood Transfusion*history of surgery & 10.640 & .031 \\
\hline Blood Transfusion*history of dental treatment & 1.163 & .884 \\
\hline Blood Transfusion*effected mother to child & 7.471 & 0.113 \\
\hline Blood Transfusion*prick of ear and nose & 5.736 & .220 \\
\hline Blood Transfusion*sexual relation with affected person & 10.34 & 0.010 \\
\hline Blood Transfusion*through affected blood & 10.37 & 0.012 \\
\hline
\end{tabular}

To check the association of blood transfusion with different variables the chi-square test was applied. Results showed that high risk variables are strongly associated with blood transfusion such as hepatitis spread through re-use of syringes, any family member have liver disease, tattoo making, sexual relationship with affected person and through affected blood with $\mathrm{p}$ value $<0.05$ the level of significance (see table 3 ).

Table 4. Results of Mann-Whitney U test with gender and area of the respondents.

\begin{tabular}{|l|l|l|l|l|l|l|}
\hline \multicolumn{2}{|l|}{} & No & Mean Rank & $\begin{array}{l}\text { Sum } \\
\text { Rank }\end{array}$ & $\begin{array}{l}\text { Value Mann-Whitney } \\
\text { U Test }\end{array}$ & p-value \\
\hline Knowledge about & Male & 257 & 190.32 & 48912.50 & 15759.500 & .005 \\
Hepatitis B and C & Female & 143 & 218.79 & 31287.50 & & \\
\hline Knowledge about & Rural & 202 & 195.10 & 39410.00 & 18907.00 & .266 \\
Hepatitis B and C & Urban & 198 & 206.01 & 40790.00 & & \\
\hline
\end{tabular}

Mann-Whitney U test was also applied (see table 4) to investigate the knowledge about Hapatitis B and $\mathrm{C}$ among male and female of the rural and urban area. It was concluded that there is difference between male and female regarding knowledge about hepatitis $\mathrm{B}$ and $\mathrm{C}$ with value of $\mathrm{u}$ is 15759.500 and $\mathrm{p}$-value is 0.005 which is less than level of significance. On the other hand, value of $u$ is 18907.000 and p-value is 0.266 which is greater than level of significance and we conclude that there is no difference between rural and urban areas regarding to knowledge about hepatitis $\mathrm{B}$ and $\mathrm{C}$.

Kruskal-Wallis $\mathrm{H}$ test was also applied to investigate the knowledge of hepatitis B and C among education level of the people (see table 5). It has been observed that the knowledge about hepatitis among the highly educated is more then the respondents having primary and secondary education with p-value 0.000 which is less then level of significance. 
Table 5. Result of Kruskal-Wallis H test with education of the respondents.

\begin{tabular}{|l|l|l|l|l|}
\hline & Education & No & Mean Rank & p-value \\
\hline Knowledge about & Primary & 105 & 233.69 & 0.000 \\
Hepatitis B and C & Secondary & 161 & 211.36 & \\
& Graduate & 100 & 160.68 & \\
& Post Graduate & 24 & 163.68 & \\
\hline
\end{tabular}

\section{Summary and Conclusions}

The objective of the present study were to investigate the risk factor of hepatitis among the people of Azad Jammu \& Kashmir Muzaffarabad and also to check the prevalence of hepatitis B and C in the presence of different risk factors. Respondents from rural and urban area almost have same knowledge about hepatitis B and C. There was difference between male and female respondents about knowledge and awareness about hepatitis $\mathrm{B}$ and $\mathrm{C}$. It is concluded from the study that educated people have more knowledge about hepatitis B and C as compared to uneducated people. It was also observed that Tattoo making, un-safe sex or sex with affected person, re-use of syringes and un screened blood transfusion are the major risk factor of hepatitis B and C.

Proper sterilization of dental and surgical instruments must be carried out. To prevent the spread of $\mathrm{HBV}$ and HCV, people must be educated about these infections and modes of transmission ${ }^{[10]}$. Mass media campaigns should be started to raise the awareness among people about hepatitis B and C. Government should start the awareness programs and project to combat this major threat. Clinicians particularly gastroenterologist, hepatologists and other medical and practitioners should be made aware of the danger of twin infection ${ }^{[12]}$.

\section{References}

[1] Muhammad Arif Mahmood, Shireen Khawar, Abdul Hameed Anjum, Siraj Munir Ahmed, Shahid Rafiq, Imran Nazir, Muhammad Usman. "Prevalence of Hepatitis B, C and HIV infection in blood donors of Multan region". Ann King Edward Med Coll. Oct - Dec 2004; 10 (4): 459-61.

[2] Malik IA, Kaleem SA, Tariq WUZ. "Hepatitis $C$ infection. Where do we stand?" (Editorial) J College of Physcians and Surgeons Pakistan 1999; 9 (4): 234-37.

[3] Z. Liu and J. Hou, “Hepatitis B virus ( $H B V$ ) and hepatitis C virus (HCV) dual infection,” International Journal of Medical Sciences, vol. 3, no. 2, pp. 57-62, 2006.

[4] Khuwaja AK, Qureshi R. "Knowledge and Attitude about Hepatitis B and C among patients attending Family Medicine Clinics in Karachi”. Eastern Mediterranean Health J 2002; 8(6): 1-6

[5] Kumar A, L. Saima. "Screening of B and C among People Visiting General Practice Clinics in Rural Dist. Of Sindh, Pakistan". J Ayub Med Coll Abbotabad 2010; 22(4).

[6] "Hepatitis B Vaccine Loses Effectiveness in Older Adults." Vaccine Weekly January 29, 2003: 23.

[7] I. Ahmad, S. B. Khan, Rahman, H. u, M. H. Khan, and S. Anwar, "Frequency of hepatitis B and hepatitis C among cataract patients," Gomal Journal of Medical Sciences, vol. 4, pp. 61-64, 2006.

[8] Abou,M.A, A.,Eltahir, Y.M. \& Ali,A.S. (2009). "Seroprevalence of hepatitis B and C virus among blood donors in Nayla, South Dar Fur,Sudan", Virology Journal,6,146.

[9] E. R. Charles, R. Fanjansoa, R. Maherisoa, R. Vaomalala, R. Richter, R. Rindara, et al.,"Seroprevalence of hepatitis C and associated risk factors in urban areas of Antananarivo, Madagascar," BMC Infectious Diseases, vol. 8, article 25, 2008.

[10] Ayele G.A; "Prevalence and Risk Factors of Hepatitis B and Hepatitis C Virus Infections among Patients with Chronic Liver Diseases in Public Hospitals in Addis Ababa Ethiopia” ISRN Tropical Medicine 2013.

[11] P. Pasquini, L. Bisanti, L. Soldo et al., "Hepatitis B infections in the Arsi region of Ethiopia," European Journal of Epidemiology, vol. 4, no. 3, pp. 310-313, 1988

[12] Khan A U, “True Prevalence of twin HDV-HBV Infection in Pakistan: A Molecular Approach” Virology gournal 2011, 8:420.

Questionnaire

Appendix

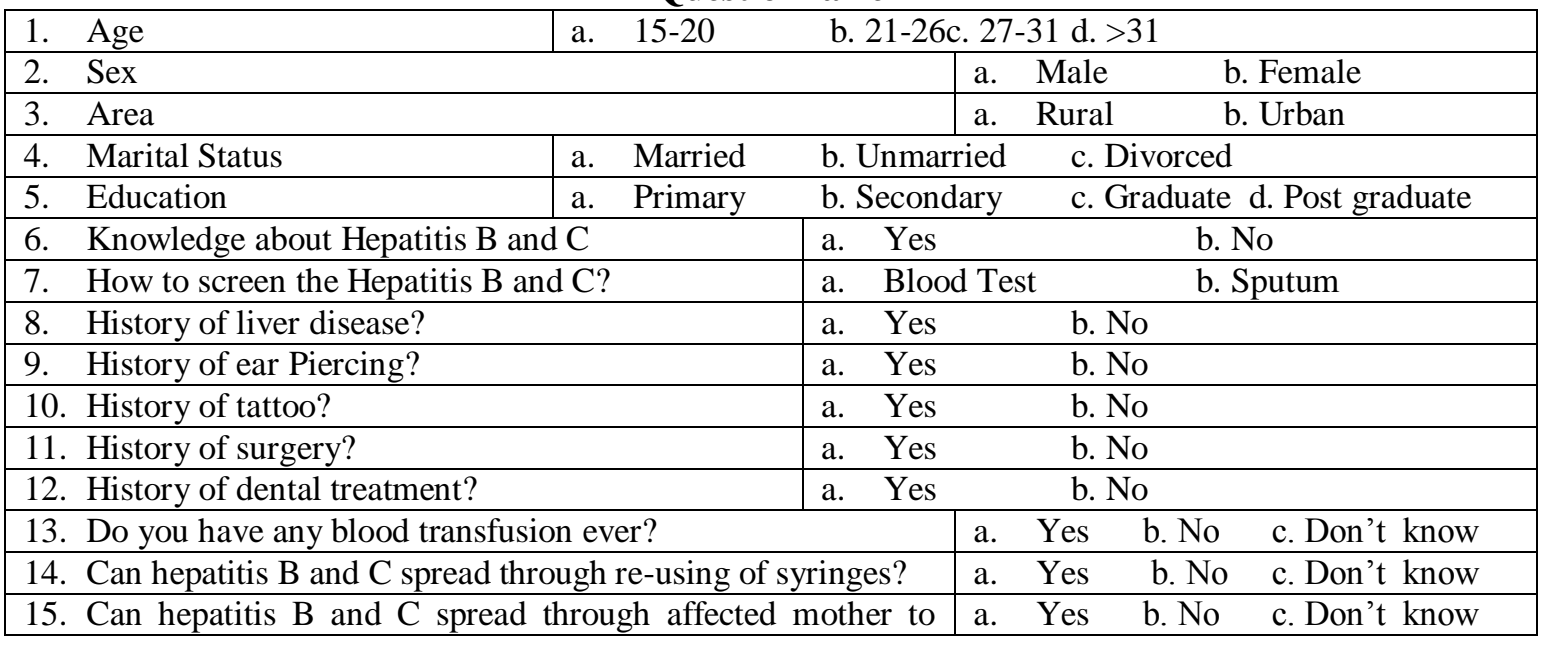




\begin{tabular}{|l|l|}
\hline child? & \multicolumn{2}{|c|}{} \\
\hline 16. Can hepatitis B and C spread through prick of ear and nose? & a. Yes b. No c. Don't know \\
\hline $\begin{array}{l}\text { 17. Can hepatitis B and C spread through sexual relation with } \\
\text { affected person? }\end{array}$ & a. Yes b. No c. Don't know \\
\hline 18. Have you ever suffered from Hepatitis B and C? & a. Yes \\
\hline 19. Is it possible to save from hepatitis B and C? & a. Yes b. No c. Don't know \\
\hline 20. Is there any treatment available for hepatitis B and C? & a. Yes b. No c. Don't know \\
\hline
\end{tabular}

